\begin{tabular}{l|l|l|l} 
Cose Reports in & $\begin{array}{l}\text { Case Rep Neurol 2009;1:47-53 } \\
\text { D01: 10.1159/000259906 }\end{array}$ & Published online: December 2, 2009 & $\begin{array}{l}\odot \text { 2009 S. Karger AG, Basel } \\
\text { ISSN 1662-680X } \\
\text { www.karger.com/crn }\end{array}$ \\
\hline
\end{tabular}

\title{
Calciphylaxis as a Catastrophic Complication in a Patient with POEMS Syndrome
}

\author{
Akiyo Hineno $^{a} \quad$ Tomomi Kinoshita $^{a}$ Michiaki Kinoshita ${ }^{a}$ \\ Fuyuko Arakura $^{\mathrm{b}}$ Ko-suke Naito ${ }^{\mathrm{a}}$ Yasuhiro Shimojima ${ }^{\mathrm{a}}$ \\ Masayuki Matsuda ${ }^{a}$ Kunihiro Yoshida ${ }^{a}$ Shu-ichi Ikeda ${ }^{a}$ \\ Departments of a Medicine (Neurology and Rheumatology), and ${ }^{b}$ Dermatology, \\ Shinshu University School of Medicine, Matsumoto, Japan
}

\section{Key Words}

Calciphylaxis · POEMS syndrome - Vascular calcification · Vascular endothelial growth factor (VEGF)

\begin{abstract}
Calciphylaxis is a vascular calcification-cutaneous necrosis syndrome, usually seen in patients with end-stage renal disease and secondary hyperparathyroidism. We report a 57-year-old polyneuropathy, organomegaly, endocrinopathy, monoclonal gammopathy, and skin changes (POEMS) syndrome patient complicated with extensive skin ulcers due to calciphylaxis. He first noted a painful cutaneous ulcer on his left thigh, and then skin lesions rapidly worsened, resulting in multiple intractable ulcers with gangrene on his legs and trunk in a few months. Serum vascular endothelial growth factor (VEGF) was markedly elevated. Biopsy samples from his skin ulcers showed the deposition of calcium in the medial layer of cutaneous vessels, this finding being compatible with calciphylaxis. This is the second reported case with POEMS syndrome complicated with calciphylaxis. Both patients had no evidence of renal failure, hyperparathyroidism, or clotting disorders. The pathogenic link between POEMS syndrome and calciphylaxis is still unclear, but VEGF is known to regulate vascular calcification, in cooperation with bone morphogenetic proteins. Further, corticosteroid and several proinflammatory cytokines activate nuclear factor-KB pathway, known as the final common pathway leading to vascular calcification. Taken together, we consider that POEMS syndrome can be an independent risk condition for calciphylaxis.
\end{abstract}

\section{Introduction}

Calciphylaxis is a rare, but life-threatening disease characterized by progressive cutaneous necrosis and ulceration secondary to small- and medium-sized vessel 
calcification [1-3]. It is also known as the 'vascular calcification-cutaneous necrosis syndrome'. End-stage renal disease and hyperparathyroidism have been considered as major causes for calciphylaxis, but many other conditions can be associated with calciphylaxis [1-4]. Chronic inflammation and prolonged corticosteroid administration have recently been reported as calciphylaxis-inducible conditions in non-uremic cases [5, 6], although their precise mechanism has been poorly understood. Many kinds of management for calciphylaxis have been tried [1-3], but there is still no effective treatment available. The main cause of death in calciphylaxis patients is fatal bacterial infection due to the destruction of the cutaneous defense system [1-3]. The total mortality rate has been reported to range from $60-80 \%$ [1].

On the other hand, polyneuropathy, organomegaly, endocrinopathy, monoclonal gammopathy, and skin changes (POEMS) syndrome is a rare multisystem disorder caused by plasma cell dyscrasia, often requiring long-term corticosteroid therapy [7]. Vascular endothelial growth factor (VEGF) has been implicated in the pathogenesis of POEMS syndrome and the serum level of VEGF is parallel to the disease activity [8-10]. As included in the disease acronym, skin changes are one of the major features in POEMS syndrome; they are hyperpigmentation, skin thickening, hypertrichosis, cherry angioma, white nails, clubbing, flushing and peripheral cyanosis [7]. To our knowledge, however, only one case with POEMS syndrome has been reported to be associated with calciphylaxis [11].

Here we report a Japanese patient who developed calciphylaxis 11 years after the onset of POEMS syndrome. The pathogenic link between POEMS syndrome and calciphylaxis is briefly discussed.

\section{Case Report}

A 57-year-old male with an 11-year history of POEMS syndrome was admitted to our hospital because of painful skin ulcers and edema. The first sign of POEMS syndrome was lower limb weakness and numbness. The diagnosis of POEMS syndrome had been made on the basis of polyneuropathy, lymphadenopathy, gynecomastia, monoclonal gammopathy (IgG $\lambda$ type), skin pigmentation and hypertrichosis with elevated serum VEGF levels. Biopsy specimens from his sural nerve tissue showed axonal degeneration with myelin ovoid and endoneurial edema, in agreement with the histological diagnosis of polyneuropathy associated with POEMS syndrome. Cervical lymph node biopsy showed the finding compatible with hyaline vascular type Castleman's disease. Bone survey did not reveal any sclerotic or lytic bone lesions, and bone marrow aspiration showed normal or slightly hypercellular marrow without plasma cell proliferation. In spite of corticosteroid therapy with additional intravenous immunoglobulin therapy or oral azathioprine therapy, the disease gradually worsened. The patient refused treatment with conventional chemotherapy or high-dose melphalan chemotherapy combined with peripheral blood stem cell transplantation for plasma cell dyscrasia.

He first noted an ulcer on his left thigh 6 months before the present admission. The skin lesion was resistant to conventional skin care and treatment, and worsened gradually. He showed severe and painful ulcers with gangrene on his bilateral thighs on admission (fig. 1a). The circumference of each ulcer seemed to be ischemic. Marked pitting edema was seen on his trunk and extremities. Laboratory examination showed slight leukocytosis and hypoalbuminemia (table 1). Serum calcium concentration revised with albumin level, phosphorus concentration and parathyroid hormone level showed normal values. The concentration of serum VEGF was markedly higher than observed earlier (table 1, fig. 2 ). Though immunological examination showed slightly elevated anti-cardiolipin antibody levels, lupus anticoagulant level was normal. Protein $\mathrm{C}$ and protein S, as well as other coagulation regulatory factors, were within normal levels. Microbial examination of the ulcerous tissue was negative for any microorganism. Disseminated calcification of vascular walls, especially in cutaneous vessels, was demonstrated with X-ray photography (fig. 3a) and computed tomography (CT) (fig. 3b). No calcification was evident on the X-ray photograph of the same site 2 years before the present admission. Thoracic CT demonstrated left pleural effusion. A biopsy specimen from the skin ulcer on his left thigh proved proliferation of endothelial cells and calcification in several cutaneous small-sized vessels (fig. 


\begin{tabular}{l|l|l|l} 
Cose Reports in & $\begin{array}{l}\text { Case Rep Neurol 2009;1:47-53 } \\
\text { D0l: } 10.1159 / 000259906\end{array}$ & & $\begin{array}{l}\text { Published online: December 2, 2009 S. Karger AG, Basel } \\
\text { ISSN 1662-680X } \\
\text { www.karger.com/crn }\end{array}$ \\
\hline
\end{tabular}

1c, d). According to clinical features, radiographic and histological findings, the diagnosis of calciphylaxis was confirmed.

To prevent the progression of POEMS syndrome and calciphylaxis, combination therapy using melphalan ( $0.22 \mathrm{mg} / \mathrm{kg} /$ day, for 4 days), dexamethasone (40 mg/day, for 4 days) and the anti-VEGF agent, thalidomide (100 mg/day, daily use), was started. The serum VEGF concentration drastically decreased after the initiation of this combination therapy, but the calciphylaxis remained uncontrollable. His skin ulcerations extended to the bilateral legs and trunk in a few months (fig. 1b). Additional hyperbaric oxygen (HBO) therapy and bisphosphonates failed to repress calciphylaxis. He died of sepsis 17 months after the onset of calciphylaxis.

\section{Discussion}

Most cases with calciphylaxis reported so far have been associated with end-stage renal disease and secondary hyperparathyroidism [1-3]. However, there is growing evidence that this entity is associated with several non-uremic diseases such as malignancy, alcoholic liver disease, collagen-vascular diseases, diabetes and inflammatory bowel disease [1-4]. This clearly indicates that the etiology of calciphylaxis is multifactorial. The possible risk conditions or trigger factors for calciphylaxis in non-uremic diseases include chronic inflammatory state, systemic hypercoagulable state, and chronic immunosuppressive state [1-4].

To date, coexistent POEMS syndrome and calciphylaxis has been reported only in one patient [11]. De Roma et al. reported a 46-year-old Italian woman who developed calciphylaxis 34 months after the diagnosis of POEMS syndrome. Both the case of De Roma et al. and ours lacked the well-known risk conditions such as renal failure, hyperparathyroidism, or clotting disorders. Although the VEGF values were not described in that case, a high dose of corticosteroid was used [11]. These cases indicate that POEMS syndrome can be an independent risk condition for the development of calciphylaxis in certain circumstances.

Vascular calcification is thought to result from imbalance between bone deposition and resorption $[12,13]$. Various bone-regulating proteins are involved in the process of vascular calcification $[12,13]$. RANKL (receptor activator of nuclear factor- $\kappa \mathrm{B}(\mathrm{NF}-\kappa \mathrm{B})$ ligand) and its antagonist, osteoprotegerin (OPG), play a critical role in bone remodeling $[12,13]$. The activation of RANK-mediated NF- $\kappa B$ pathway causes osseous mineral loss and extraosseous (vascular) mineral deposition. The pathogenic link between calciphylaxis and POEMS syndrome calls for further discussion. Chronic deregulation of VEGF and proinflammatory cytokines has been implicated in the pathogenesis of POEMS syndrome [7]. In particular, the level of serum VEGF is widely used as a marker of disease activity in POEMS syndrome [8-10]. Interestingly, it is reported that VEGF regulates calcification in cultured vascular smooth muscle cells, or other type of cells, in cooperation with bone morphogenetic proteins (BMPs) [14, 15]. Furthermore, corticosteroid, as well as parathyroid hormone, is known to activate RANK-mediated NF$\kappa B$ pathway and to inhibit OPG [12].Thus, a long-term corticosteroid administration is likely to promote osseous mineral loss and vascular calcification. Several proinflammatory cytokines, namely interleukin- 1 and tumor necrosis factor- $\alpha$, may promote vascular calcification by activating RANK-mediated NF- $\kappa B$ pathway [12]. Taken together with these evidences, it is very likely that POEMS syndrome is a possible risk condition for calciphylaxis.

In conclusion, we report the second case of POEMS syndrome complicated with calciphylaxis. The precise causes for calciphylaxis in our patient remain unsolved, but we 


\begin{tabular}{l|l|l|l} 
Cose Reports in & $\begin{array}{l}\text { Case Rep Neurol 2009;1:47-53 } \\
\text { Dol: } 10.1159 / 000259906\end{array}$ & & $\begin{array}{l}\text { Published online: December 2, 2009 S. Karger AG, Basel } \\
\text { ISSN 1662-680X } \\
\text { www.karger.com/crn }\end{array}$ \\
\hline
\end{tabular}

speculate that the sustained elevation of serum VEGF levels and the long-term administration of corticosteroids could contribute to the development of calciphylaxis. Our trial with an anti-VEGF agent failed to control calciphylaxis, but the initiation of anti-VEGF therapy in the earlier stage of the disease could prevent or delay the development of calciphylaxis.

Table 1. Laboratory findings on admission

\begin{tabular}{lc}
\hline Variable & Value (normal range) \\
\hline White blood cell count, $\times 10^{3} / \mu \mathrm{l}$ & $11.82(2.97-9.13)$ \\
$\quad$ Neutrophils, \% & $95.0(28.0-78.0)$ \\
Hemoglobin, g/dl & $14.9(12.9-17.4)$ \\
Platelet, $\times 10^{4} / \mu \mathrm{l}$ & $26.6(14.3-33.3)$ \\
C-reactive protein, mg/dl & $0.20(<0.10)$ \\
Albumin, g/dl & $2.9(4.2-5.1)$ \\
Urea nitrogen, mg/dl & $24(9-22)$ \\
Creatinine, $\mathrm{mg} / \mathrm{dl}$ & $0.58(0.60-1.00)$ \\
Calcium, $\mathrm{mg} / \mathrm{dl}$ & $7.6(8.6-10.1)$ \\
$\quad$ Corrected calcium, $\mathrm{mg} / \mathrm{dl}$ & $8.7(8.7-9.9)$ \\
Phosphate, $\mathrm{mg} / \mathrm{dl}$ & $3.6(2.2-4.1)$ \\
PT $(\mathrm{INR})$ & $1.02(0.85-1.15)$ \\
APTT, s & $28.6(23.0-38.0)$ \\
Protein C, \% & $82(70-140)$ \\
Protein $\mathrm{S}, \%$ & $78.8(60.0-150.0)$ \\
Lupus anticoagulant $(\mathrm{ratio})$ & $1.05(0.00-1.29)$ \\
aCL/ $\beta 2 \mathrm{GPI}$ antibody, $\mathrm{U} / \mathrm{ml}$ & $4.0(0.0-3.4)$ \\
intact PTH, pg/ml & $31.8(10.0-65.0)$ \\
PTHrP, pmol/l & $<1.0(0.0-1.1)$ \\
Prolactin, ng/ml & $21.2(1.5-9.7)$ \\
Estradiol, pg/ml & $15(20-59)$ \\
Cortisol, $\mu \mathrm{mg} / \mathrm{dl}$ & $2.5(5.0-15.0)$ \\
Renin, $\mathrm{ng} / \mathrm{ml} / \mathrm{h}$ & $0.3(0.2-3.1)$ \\
Aldosterone, pg/ml & $<25.0(35.7-240.0)$ \\
VEGF, pg/ml & $4,240(0-115)$ \\
IL-6, pg/ml & $0.827(<2.41)$ \\
\hline
\end{tabular}

$\mathrm{PT}=$ prothrombin time; APTT = activated partial thromboplastin time; $\mathrm{aCL} / \beta 2 \mathrm{GPI}=$ anticardiolipin$\beta 2$ glycoprotein; $\mathrm{PTH}=$ parathyroid hormone; $\mathrm{PTHrP}=$ parathyroid hormone related peptide; $\mathrm{VEGF}=$ vascular endothelial growth factor; IL-6 = interleukin-6. 


\begin{tabular}{l|l|l|l} 
Cose Reports in & $\begin{array}{l}\text { Case Rep Neurol 2009;1:47-53 } \\
\text { D01: } 10.1159 / 000259906\end{array}$ & Published online: December 2, 2009 & $\begin{array}{l}\text { @ 2009 S. Karger AG, Basel } \\
\text { ISSN 1662-680X } \\
\text { www.karger.com/crn }\end{array}$ \\
\hline
\end{tabular}

Fig. 1. Calciphylaxis-induced skin changes at admission (a left thigh). A spread of the ulcer had expanded to the bilateral legs and trunk in a few months (b lower trunk and bilateral thighs). Histology of biopsy specimen from the ulcer on the left thigh showed classic findings of calciphylaxis including intimal hyperplasia with local fat necrosis (c) and calcium deposits (c, $\mathbf{d}$ arrowheads) in the media of small- and medium-sized arteries. $\mathbf{c}$ Hematoxylin-eosin stain; d von Kossa stain; scale bar $=100 \mu \mathrm{m}$.
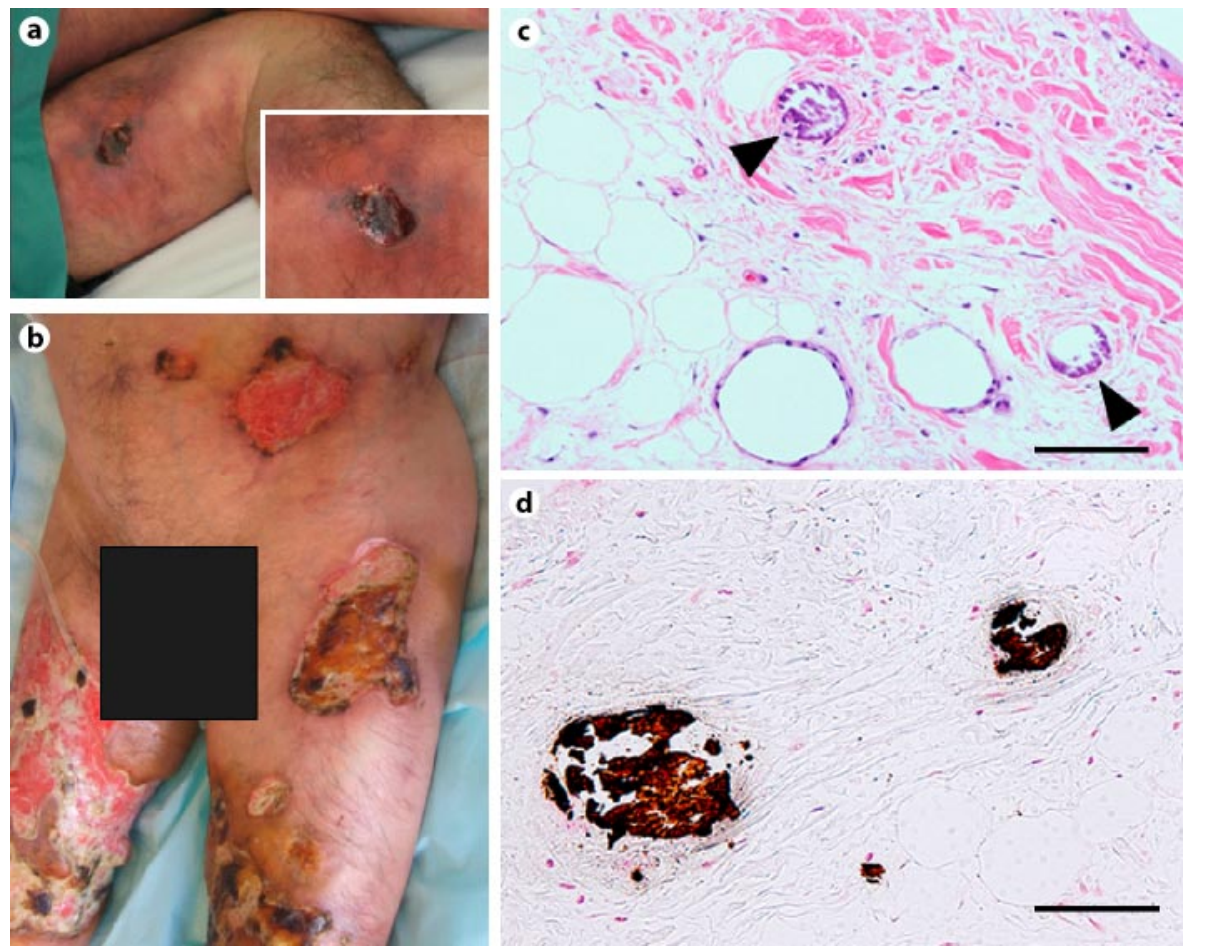

Fig. 2. Clinical time course. Corticosteroid, azathioprine and IVIg reduced serum VEGF levels and suppressed the disease activity of POEMS syndrome transiently, but the disease relapsed. The value of serum VEGF dramatically increased at the diagnosis of calciphylaxis. After treatment with M-Dex and thalidomide, the VEGF levels decreased. $\mathrm{mPSL}=$ High-dose intravenous methylprednisolone $(1 \mathrm{~g} / \mathrm{day}$, 3 days); $P S L=$ oral prednisolone $(20-60 \mathrm{mg} /$ day $) ; \mathrm{IVIg}=$ intravenous immunoglobulin $(0.4 \mathrm{~g} / \mathrm{kg} / \mathrm{day}$, 5 days); $\mathrm{M}-\mathrm{Dex}=$ melphalan $(0.22 \mathrm{mg} / \mathrm{kg} /$ day $)$ and dexamethasone $(40 \mathrm{mg} /$ day, day $1-4)$.

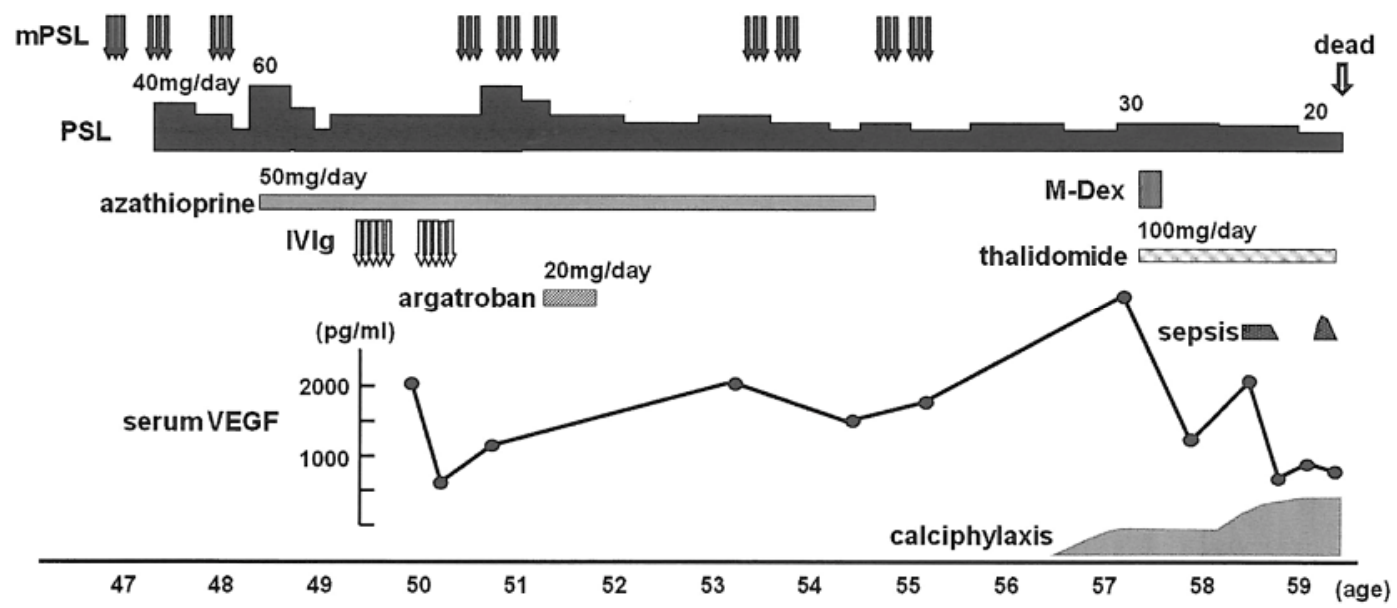




\begin{tabular}{l|l|l|l} 
Cose Reports in & $\begin{array}{l}\text { Case Rep Neurol 2009;1:47-53 } \\
\text { Dol: } 10.1159 / 000259906\end{array}$ & Published online: December 2, 2009 & $\begin{array}{l}\text { ○ 2009 S. Karger AG, Basel } \\
\text { ISSN 1662-680X } \\
\text { www.karger.com/crn }\end{array}$ \\
\hline
\end{tabular}

Fig. 3. Soft-tissue X-ray showed some calcified small- and medium-sized arterioles (a left wrist, arrowheads), and computed tomography (CT) also showed multiple subcutaneous and intramuscular calcifications (b bilateral thigh, arrowheads).

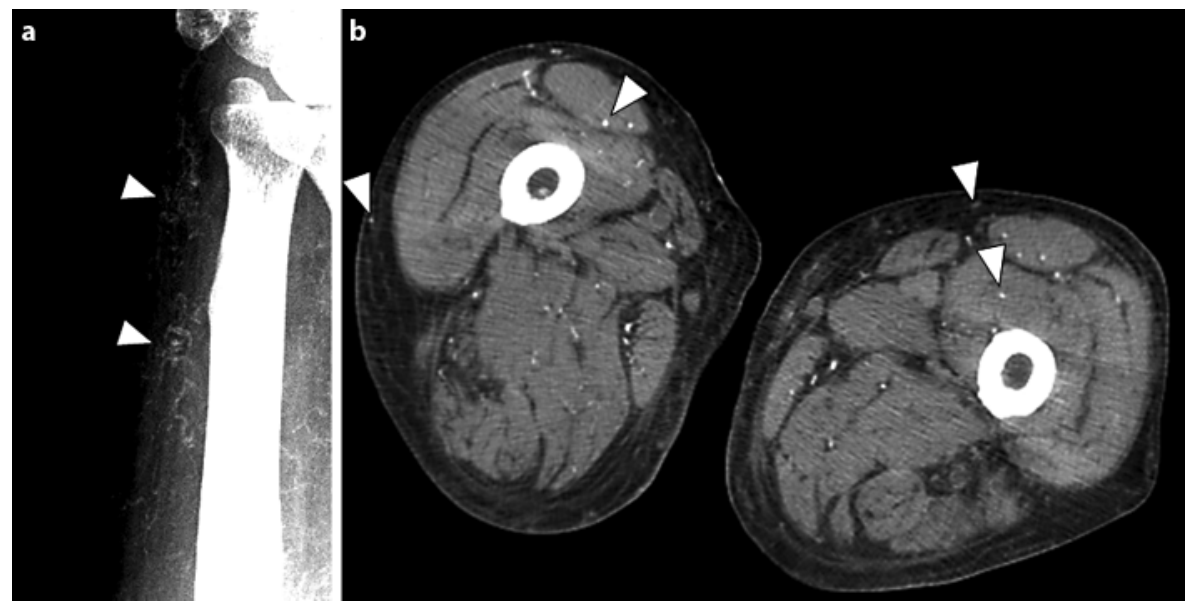




\begin{tabular}{l|l|l|l} 
Cose Reports in & $\begin{array}{l}\text { Case Rep Neurol 2009;1:47-53 } \\
\text { Dol: } 10.1159 / 000259906\end{array}$ & Published online: December 2, 2009 & $\begin{array}{l}\text { ○ 2009 S. Karger AG, Basel } \\
\text { ISSN 1662-680X } \\
\text { www.karger.com/crn }\end{array}$ \\
\hline
\end{tabular}

\section{References}

1 Arseculeratne G, Evans AT, Morley SM: Calciphylaxis - a topical overview. J Eur Acad Dermatol Venereol 2006;20:493-502.

2 Weenig RH, Sewell LD, Davis MDP, McCarthy JT, Pittelkow MR: Calciphylaxis: natural history, risk factor analysis, and outcome. J Am Acad Dermatol 2007;56:569-579.

-3 Guldbakke KK, Khachemoune A: Calciphylaxis. Int J Dermatol 2007;46:231-238.

-4 Nigwekar SU, Wolf M, Sterns RH, Hix JK: Calciphylaxis from nonuremic causes: a systematic review. Clin J Am Soc Nephrol 2008;3:1139-1143.

-5 Korkmaz C, Dündar E, Zubaroğlu I: Calciphylaxis in a patient with rheumatoid arthritis without renal failure and hyperparathyroidism: the possible role of longterm steroid use and protein S deficiency. Clin Rheumatol 2002;21:66-69.

-6 Ozbalkan Z, Calguneri M, Onat AM, Ozturk MA: Development of calciphylaxis after long-term steroid and methotroxate use in a patient with rheumatoid arthritis. Intern Med 2005;44:1178-1181.

7 Dispenzieri A: POEMS syndrome. Blood Rev 2007;21:285-299.

-8 Soubrier M, Dubost JJ, Serre AF, Ristori JM, Sauvezie B, Cathebras P, Piette JC, Chapman A, Authier FJ, Gherardi RK: Growth factors in POEMS syndrome: evidence for marked increase in circulating vascular endothelial growth factor. Arthritis Rheum 1997;40:786-787.

-9 Watanabe O, Maruyama I, Arimura K, Kitajima I, Arimura H, Hanatani M, Matsuo K, Arisato T, Osame M: Overproduction of vascular endothelial growth factor/vascular permeability factor is causative in Crow-Fukase (POEMS) syndrome. Muscle Nerve 1998;21:1390-1397.

10 Kuwabara S, Misawa S, Kanai K, Sawai S, Hattori T, Nishimura M, Nakaseko C: Thalidmide reduces serum VEGF levels and improves peripheral neuropathy in POEMS syndrome. J Neurol Neurosurg Psychiatry 2008;79:1255-1257.

-11 De Roma I, Filotico R, Cea M, Procaccio P, Perosa F: Calciphylaxis in a patient with POEMS syndrome without renal failure and/or hyperthyroidism. A case report. Ann Ital Med Int 2004;19:283-287.

12 Weenig RH: Pathogenesis of calciphylaxis: Hans Selye to nuclear factor kappa-B. J Am Acad Dermatol 2008;58:458-471.

13 Alexander MY: RANKL links arterial calcification with osteolysis. Circ Res 2009;104:1032-1034.

14 Mikhaylova L, Malmquist J, Nurminskaya M: Regulation of in vitro vascular calcification by BMP4, VEGF and Wnt3a. Calcif Tissue Int 2007;81:372-381.

15 Li G, Corsi-Payne K, Zheng B, Usas A, Peng H, Huard J: The dose of growth factors influences the synergistic effect of vascular endothelial growth factor on bone morphogenetic protein 4-induced ectopic bone formation. Tissue Eng Part A 2009;15:2123-2133. 